\title{
Study on early-warning System of Karst Tunnel Collapse
}

\author{
YU Yongyan ${ }^{1}$, MA Dong ${ }^{2}$, Fu Chongtao ${ }^{2}$ \\ ${ }^{1}$ Research Institute of Highway Ministry of Transport, Beijing 100088, China \\ ${ }^{2}$ First Engineering Co., Ltd. China Railway 16th Bureau Group Co., Ltd., Beijing 101300, China)
}

\begin{abstract}
During the construction of karst Tunnel, tunnel collapse often occurs. The establishment of early-warning system of tunnel collapse can effectively ensure the construction safety, but the research is insufficient. Based on the combination of theoretical analysis and engineering practice, this paper puts forward to early-warning system for karst tunnel collapse. (1) The evaluation index system of karst tunnel collapse is composed of anchor axial force, displacement, anchor pull-out force and steel arch stress. (2) The relationship between evaluation index and warning level is determined, and the early-warning system of tunnel collapse is established. (3) The model applied to Chong'anjiang tunnel collapse warning, and achieved good results.
\end{abstract}

\section{Introduction}

Tunnel engineering has the characteristics of many risk factors, complex construction technology and huge investment. Compared with other tunnels, the risk of collapse in karst tunnel during construction is higher. In Southwest China, more than $1 / 3$ of the carbonate areas are concentrated, which are easily to form karst areas. Tunnel collapse seriously endangers the safety of construction in Southwest China.

The establishment and application of karst tunnel collapse early-warning system can effectively ensure the safety of tunnel construction and reduce losses. However, the research on the establishment of early-warning system of tunnel collapse in karst tunnel construction is still insufficient.

Wang Tianyu ${ }^{[1]}$ established a landslide early-warning system based on tunnel characteristics and climate factors. And Zhou Xiaoyong[ 2] established a landslide early-warning model based on the mechanical properties of surrounding rock. Ma Shiwei ${ }^{[3,4]}$ has studied the establishment method of collapse early-warning system for tunnels with weak surrounding rock and loess. $\mathrm{Wu}$

Table 1 Five color early-warning degree for tunnel geological hazards

\begin{tabular}{lll}
\hline $\begin{array}{l}\text { Five color } \\
\text { warning degree }\end{array}$ & Warning limit & Explain \\
\hline Red & Giant warning & The surrounding rock is unstable and the risk of instability is very high \\
Orange & Severe warning & The stability of surrounding rock is poor and the risk of instability is high \\
Yellow & Moderate warning & The surrounding rock is basically stable, and the risk of instability is general \\
Blue & Mild warning & The stability of surrounding rock is good and the risk of instability is low \\
White & No warning & The surrounding rock is very stable and the risk of instability is very small \\
\hline
\end{tabular}

$\mathrm{Ke}^{[5]}$, put forward the establishment mode of landslide early-warning from monitoring measurement and from geological advance prediction. Xue Yiguo[ ${ }^{6}$ ] has established an early-warning system for karst tunnels by combining advanced prediction with monitoring measurement.

In this paper, based on the Chong'anjiang tunnel in Guizhou Province, fully considering the characteristics of karst tunnel collapse, the tunnel collapse early-warning system is established.

\section{Establishment of karst tunnel collapse early-warning system}

\section{$2.1 \quad$ Determination of warning degree}

Five color early-warning is established to judge the degree of harm, degree of emergency and development trend of collapse during the construction process. The warning degree is indicated by red, orange, yellow, blue and white, as shown in Table 1. 


\subsection{Evaluation index and grade}

There are many evaluation indexes that affect the stability of karst tunnel. Based on the relevant research and comprehensive analysis, the indexes of bolt axial force, displacement, bolt pull-out force and steel arch stress are selected to form the evaluation index system of tunnel stability. In order to achieve the purpose of dynamic early-warning, the geological and topographical factors of the tunnel or the tunnel itself are no longer considered here.

The evaluation indexes are divided into two levels according to the different positions of anchor and different displacement monitoring positions, as shown in Table 2

\begin{tabular}{|c|c|}
\hline Primary indicators & Secondary indicators \\
\hline \multirow[t]{3}{*}{ Bolt axial force } & Roof bolt \\
\hline & Left haunch bolt \\
\hline & Right haunch bolt \\
\hline \multirow[t]{2}{*}{ Displacement } & Vault displacement \\
\hline & Peripheral displacement \\
\hline Stress of steel arch & Stress of steel arch \\
\hline Pull out force of anchor rod & Qualified rate of anchor rod pullout force \\
\hline
\end{tabular}

(1) Test of bolt axial force

The axial force test of bolt is mainly used to understand the stress state and axial force of bolt, determine the deformation trend of surrounding rock, and finally evaluate the effect of bolt support. If the axial force of bolt is too large or too small, it will have adverse effect on the stability of surrounding rock. The risk assessment of bolt axial force test is shown in Table 3.

Table 3 Relationship between bolt axial force and early-warning level

\begin{tabular}{|c|c|c|c|c|c|}
\hline \multirow{2}{*}{$\begin{array}{l}\text { Evaluating } \\
\text { indicator }\end{array}$} & \multirow[b]{2}{*}{$\mathrm{V}$} & \multicolumn{4}{|l|}{ Warning level } \\
\hline & & IV & III & II & I \\
\hline $\begin{array}{l}\text { Roof } \\
\text { bolt }\end{array}$ & $\begin{array}{l}0.95 \mathrm{~N}_{\mathrm{s}} \leqslant \mathrm{N}_{\mathrm{i}} \\
<1.05 \mathrm{~N}_{\mathrm{s}}\end{array}$ & $\begin{array}{l}0.9 \mathrm{~N}_{\mathrm{s}} \leqslant \mathrm{N}_{\mathrm{i}}<0.95 \mathrm{~N}_{\mathrm{s}} \\
\text { Or } \\
1.05 \mathrm{~N}_{\mathrm{s}} \leqslant \mathrm{N}_{\mathrm{i}}<1.1 \mathrm{~N}_{\mathrm{s}}\end{array}$ & $\begin{array}{l}0.8 \mathrm{~N}_{\mathrm{s}} \leqslant \mathrm{N}_{\mathrm{i}}<0.9 \mathrm{~N}_{\mathrm{s}} \\
\mathrm{Or} \\
1.1 \mathrm{~N}_{\mathrm{s}} \leqslant \mathrm{N}_{\mathrm{i}}<1.2 \mathrm{~N}_{\mathrm{s}}\end{array}$ & $\begin{array}{l}0.7 \mathrm{~N}_{\mathrm{s}} \leqslant \mathrm{N}_{\mathrm{i}}<0.8 \mathrm{~N}_{\mathrm{s}} \\
\mathrm{Or} \\
1.2 \mathrm{~N}_{\mathrm{s}} \leqslant \mathrm{N}_{\mathrm{i}}<1.3 \mathrm{~N}_{\mathrm{s}}\end{array}$ & $\begin{array}{l}\mathrm{N}_{\mathrm{i}}<0.7 \mathrm{~N}_{\mathrm{s}} \\
\mathrm{Or} \\
1.3 \mathrm{~N}_{\mathrm{s}} \leqslant \mathrm{N}_{\mathrm{i}}\end{array}$ \\
\hline $\begin{array}{l}\text { Left } \\
\text { haunch } \\
\text { bolt }\end{array}$ & $\begin{array}{l}0.95 \mathrm{~N}_{\mathrm{s}} \leqslant \mathrm{N}_{\mathrm{i}}<1.05 \\
\mathrm{~N}_{\mathrm{s}}\end{array}$ & $\begin{array}{l}0.9 \mathrm{~N}_{\mathrm{s}} \leqslant \mathrm{N}_{\mathrm{i}}<0.95 \mathrm{~N}_{\mathrm{s}} \\
\mathrm{Or} \\
1.05 \mathrm{~N}_{\mathrm{s}} \leqslant \mathrm{N}_{\mathrm{i}} \\
<1.1 \mathrm{~N}_{\mathrm{s}}\end{array}$ & $\begin{array}{l}0.8 \mathrm{~N}_{\mathrm{s}} \leqslant \mathrm{N}_{\mathrm{i}}<0.9 \mathrm{~N}_{\mathrm{s}} \\
\text { Or } \\
1.1 \mathrm{~N}_{\mathrm{s}} \leqslant \mathrm{N}_{\mathrm{i}} \\
<1.2 \mathrm{~N}_{\mathrm{s}}\end{array}$ & $\begin{array}{l}0.7 \mathrm{~N}_{\mathrm{s}} \leqslant \mathrm{N}_{\mathrm{i}}<0.8 \mathrm{~N}_{\mathrm{s}} \\
\text { Or } \\
1.2 \mathrm{~N}_{\mathrm{s}} \leqslant \mathrm{N}_{\mathrm{i}}<1.3 \mathrm{~N}_{\mathrm{s}}\end{array}$ & $\begin{array}{l}\mathrm{N}_{\mathrm{i}}<0.7 \mathrm{~N}_{\mathrm{s}} \\
\text { Or } \\
1.3 \mathrm{~N}_{\mathrm{s}} \leqslant \mathrm{N}_{\mathrm{i}}\end{array}$ \\
\hline $\begin{array}{l}\text { Right } \\
\text { haunch } \\
\text { bolt }\end{array}$ & $\begin{array}{l}0.95 \mathrm{~N}_{\mathrm{s}} \leqslant \mathrm{N}_{\mathrm{i}}<1.05 \\
\mathrm{~N}_{\mathrm{s}}\end{array}$ & $\begin{array}{l}0.9 \mathrm{~N}_{\mathrm{s}} \leqslant \mathrm{N}_{\mathrm{i}}<0.95 \mathrm{~N}_{\mathrm{s}} \\
\text { Or } \\
1.05 \mathrm{~N}_{\mathrm{s}} \leqslant \mathrm{N}_{\mathrm{i}}<1.1 \mathrm{~N}_{\mathrm{s}}\end{array}$ & $\begin{array}{l}0.8 \mathrm{~N}_{\mathrm{s}} \leqslant \mathrm{N}_{\mathrm{i}}<0.9 \mathrm{~N}_{\mathrm{s}} \\
\text { Or } \\
1.1 \mathrm{~N}_{\mathrm{s}} \leqslant \mathrm{N}_{\mathrm{i}}<1.2 \mathrm{~N}_{\mathrm{s}}\end{array}$ & $\begin{array}{l}0.7 \mathrm{~N}_{\mathrm{s}} \leqslant \mathrm{N}_{\mathrm{i}}<0.8 \mathrm{~N}_{\mathrm{s}} \\
\mathrm{Or} \\
1.2 \mathrm{~N}_{\mathrm{s}} \leqslant \mathrm{N}_{\mathrm{i}}<1.3 \mathrm{~N}_{\mathrm{s}}\end{array}$ & $\begin{array}{l}\mathrm{N}_{\mathrm{i}}<0.7 \mathrm{~N}_{\mathrm{s}} \\
1.3 \mathrm{~N}_{\mathrm{s}} \leqslant \mathrm{N}_{\mathrm{i}}\end{array}$ \\
\hline
\end{tabular}

(2) Tunnel convergence displacement shown in Table 4.

The convergence displacement of tunnel includes vault settlement and peripheral displacement, as

Table 4 Relationship between convergence displacement and warning level

\begin{tabular}{|c|c|c|c|c|c|}
\hline $\begin{array}{l}\text { Evaluating } \\
\text { indicator }\end{array}$ & $\begin{array}{l}\text { Warning level } \\
\text { V }\end{array}$ & IV & III & II & I \\
\hline $\begin{array}{l}\text { Vault } \\
\text { displacement }\end{array}$ & $\begin{array}{l}\mathrm{U}_{0}<0.6 \mathrm{U}_{\mathrm{n}} \\
\text { no inflection point } \\
\text { in the displacement } \\
\text {-time curve }\end{array}$ & $\begin{array}{l}0.6 \mathrm{U}_{\mathrm{n}}<\mathrm{U}_{0}<0.8 \mathrm{U}_{\mathrm{n}} \\
\text { no inflection point } \\
\text { in the } \\
\text { displacement-time } \\
\text { curve }\end{array}$ & $\begin{array}{l}0.8 \mathrm{U}_{\mathrm{n}}<\mathrm{U}_{0}<\mathrm{U}_{\mathrm{n}} \\
\text { no inflection point } \\
\text { in the } \\
\text { displacement-time } \\
\text { curve }\end{array}$ & $\begin{array}{l}\mathrm{U}_{\mathrm{n}}<\mathrm{U}_{0} \\
\text { no inflection point } \\
\text { in the } \\
\text { displacement-time } \\
\text { curve }\end{array}$ & $\begin{array}{l}\text { There is inflection } \\
\text { point in the } \\
\text { displacement-time } \\
\text { curve }\end{array}$ \\
\hline $\begin{array}{l}\text { Perip } \\
\text { displ }\end{array}$ & $\begin{array}{l}\mathrm{U}_{0}<0.6 \mathrm{U}_{\mathrm{n}} \\
\text { no inflection point } \\
\text { in the } \\
\text { displacement-time } \\
\text { curve }\end{array}$ & $\begin{array}{l}0.6 \mathrm{U}_{\mathrm{n}}<\mathrm{U}_{0}<0.8 \mathrm{U}_{\mathrm{n}} \\
\text { no inflection point } \\
\text { in the } \\
\text { displacement-time } \\
\text { curve }\end{array}$ & $\begin{array}{l}0.8 \mathrm{U}_{\mathrm{n}}<\mathrm{U}_{0}<\mathrm{U}_{\mathrm{n}} \\
\text { no inflection point } \\
\text { in the } \\
\text { displacement-time } \\
\text { curve }\end{array}$ & $\begin{array}{l}\mathrm{U}_{\mathrm{n}}<\mathrm{U}_{0} \\
\text { no inflection point } \\
\text { in the } \\
\text { displacement-time } \\
\text { curve }\end{array}$ & $\begin{array}{l}\text { There is inflection } \\
\text { point in the } \\
\text { displacement-time } \\
\text { curve }\end{array}$ \\
\hline $\begin{array}{l}\text { The } t \\
\text { ximun }\end{array}$ & T 11 & & \multicolumn{3}{|c|}{$\begin{array}{l}\text { comprehensive reflection of the quality of bolt materia } \\
\text { processing and construction and installation. Whether th } \\
\text { pull-out force of the bolt meets the requirements directl } \\
\text { affects the effect of the bolt. When the pull-out force } \\
\text { the bolt is insufficient, it can not play the role o }\end{array}$} \\
\hline
\end{tabular}


anchoring the surrounding rock, so the detection of the tensile pull-out force of the bolt is very important.

According to (JTJ 042-94), at least three anchors shall be selected randomly for each installation of 300 anchors, and the three bolts shall be taken as a group for pull-out test in the same section, and another group shall be conducted when the surrounding rock changes.

Table 5 Relationship between pullout resistance of bolt and warning level

\begin{tabular}{|c|c|c|c|c|c|}
\hline \multirow[t]{2}{*}{ Evaluating indicator } & \multicolumn{5}{|c|}{ Warning level } \\
\hline & $\mathrm{V}$ & IV & III & II & I \\
\hline Qualified rate of anchor rod pullout force & $90 \%-100 \%$ & $80 \%-90 \%$ & $65 \%-80 \%$ & $50 \%-65 \%$ & Less than $50 \%$ \\
\hline
\end{tabular}
the stability of tunnel support system. The stability of

Table 6 Relationship between Stress of steel arch and warning level

\begin{tabular}{lll}
\hline Evaluating indicator & \multicolumn{2}{l}{ Warning level } \\
& $\mathrm{V}$ & $\mathrm{IV}$ \\
\hline $\begin{array}{l}\text { Stress variation of steel arch } \\
(\mathrm{mm} / \mathrm{d})\end{array}$ & $\sigma \leqslant 0.8[\sigma]$ & 0.8 \\
\hline \multicolumn{2}{c}{ Determination of alarm degree and } \\
\end{tabular}

The determination of the alarm degree is generally based on the data and change of the monitoring indicators. If the index value falls in a certain alarm

\begin{tabular}{|c|c|c|}
\hline $\begin{array}{l}\text { Five color } \\
\text { warning } \\
\text { degree }\end{array}$ & Warning limit & Explain \\
\hline Red & Giant warning & $\begin{array}{l}\text { The warning level of any index is grade I, or two or more indicators are grade II, and the } \\
\text { change trend is increasing }\end{array}$ \\
\hline Orange & Severe warning & $\begin{array}{l}\text { No warning level is higher than grade I, and there is one index whose warning level is grade } \\
\text { II }\end{array}$ \\
\hline Yellow & $\begin{array}{l}\text { Moderate } \\
\text { warning }\end{array}$ & $\begin{array}{l}\text { No warning level is higher than grade II, and there is one index whose warning level is } \\
\text { grade III }\end{array}$ \\
\hline Blue & Mild warning & $\begin{array}{l}\text { No warning level is higher than grade III, and there is one index whose warning level is } \\
\text { grade IV }\end{array}$ \\
\hline White & No warning & The warning level of all indicators is grade IV. \\
\hline
\end{tabular}

\section{Early-warning and treatment}

Based on the summary of experts' opinions and

\begin{tabular}{ll}
\hline $\begin{array}{c}\text { Five color } \\
\text { warning degree }\end{array}$ & \multicolumn{1}{c}{ Treatment } \\
\hline Red & $\begin{array}{l}\text { Stop work and reinforce the process that may cause harm. If necessary, evacuate the non construction } \\
\text { personnel in the dangerous area } \\
\text { When a large area of overall collapse endangers the safety of construction personnel, all construction } \\
\text { personnel shall be evacuated. }\end{array}$ \\
& $\begin{array}{l}\text { Some processes can be constructed normally, but the processes that may cause harm must be stopped. } \\
\text { Orange }\end{array}$ \\
& $\begin{array}{l}\text { If necessary, evacuate all non construction personnel in the dangerous area. } \\
\text { Continuous monitoring of geological hazards. }\end{array}$ \\
Sellow & Continuous monitoring of geological hazards. \\
Blue & All kinds of working procedures can still be carried out normally, and the monitoring should be strengthened. \\
white & Normal construction of various processes
\end{tabular}

\section{Engineering examples}

\section{1}

\section{Overview}

Chong'anjiang tunnel is a karst tunnel, which is a referring to the existing research results, the construction treatment of each early-warning level are determined, as shown in Table 8.

limit area, it is determined as the corresponding alarm degree.

The division of alarm degree and alarm limit is shown in Table 7.

shown in Table 7. 
the length is $2720 \mathrm{~m}$, and the maximum buried depth is about $345 \mathrm{~m}$.

Taking the tunnel application in a certain mileage section as an example, the accuracy of the model is verified.

\section{2 collapse}

According to Table 2 to Table 6, the early-warning level of tunnel collapse in certain mileage section is determined, as shown in Table 9.

Table 9 Tunnel stability index system

\begin{tabular}{|c|c|c|c|}
\hline Primary indicators & Secondary indicators & Indicators & $\begin{array}{l}\text { Warning } \\
\text { level }\end{array}$ \\
\hline \multirow[t]{3}{*}{ Bolt axial force } & Roof bolt & $1.3 \mathrm{~N}_{\mathrm{s}} \leqslant \mathrm{N}_{\mathrm{i}}$ & I \\
\hline & Left haunch bolt & $1.2 \mathrm{~N}_{\mathrm{s}} \leqslant \mathrm{N}_{\mathrm{i}}<1.3 \mathrm{~N}_{\mathrm{s}}$ & II \\
\hline & Right haunch bolt & $1.2 \mathrm{~N}_{\mathrm{s}} \leqslant \mathrm{N}_{\mathrm{i}}<1.3 \mathrm{~N}_{\mathrm{s}}$ & II \\
\hline \multirow[t]{2}{*}{ Displacement } & Vault displacement & $\begin{array}{l}\text { There is inflection point in the } \\
\text { displacement-time curve }\end{array}$ & I \\
\hline & Peripheral displacement & $\begin{array}{l}\mathrm{U}_{0}<0.6 \mathrm{U}_{\mathrm{n}} \\
\text { no inflection point in the displacement-time } \\
\text { curve }\end{array}$ & V \\
\hline Stress of steel arch & Stress of steel arch & $0.85[\sigma]<\sigma \leqslant 0.9[\sigma]$ & III \\
\hline $\begin{array}{l}\text { Pull out force of anchor } \\
\text { rod }\end{array}$ & $\begin{array}{l}\text { Qualified rate of anchor rod } \\
\text { pullout force }\end{array}$ & $90 \%-100 \%$ & $\mathrm{~V}$ \\
\hline
\end{tabular}

According to Table 9, the early-warning level of tunnel collapse in certain mileage section is I, Warning degree is red.

In view of the red warning issued in this mileage section, timely measures were taken during the construction process, including: stopping the excavation and closing with $\mathrm{C} 20$ shotcrete; adding I22 steel arch protection with the same spacing as permanent steel frame; adding I22 temporary inverted arch, large lock foot and soil nailing according to the monitoring data; radial grouting with $\Phi 42$ self-propelled anchor rod with a length of $4.5 \mathrm{~m}$, spacing of $1.5 \mathrm{~m} \times 1.5 \mathrm{~m}$, injection of double liquid slurry.

After the reinforcement measures are adopted, the initial support of each section has a large growth rate in 5-8 days, which is in a slow growth period in 8-20 days, and tends to converge after 20 days.

\section{Conclusion}

Based on the combination of theoretical analysis and engineering practice, this paper puts forward to early-warning system for karst tunnel collapse.

(1) The evaluation index system of tunnel collapse is composed of anchor axial force, displacement, anchor pull-out force and steel arch stress.

(2) The relationship between evaluation index and warning level is determined, and the early-warning system of tunnel collapse is established.

(3) The model applied to Chong'anjiang tunnel collapse warning, and achieved good results.

\section{Reference}

1. WANG Tianyu, QU Lina, Ni Lizhi, et al. Early warning of karst tunnel collapse risk based on uncertainty measurement theory[J].Journal of Xi'an University of Science and Technology,2020,40(02):284-291.

2. ZHOU Xiaoyong. Tunnel Collapse risk Warning Model
Based on Efficacy Coefficient Method and Geological Prediction and its Applications[J].Highway Engineering,2015,40(02):59-63.

3. MA Shiwei, HAN Xuequan, LIAO Kai,et al. Warning Standards Study of Real-time Monitoring for Anti-collapse in Large Cross-section Tunnel of Soft and Weak Surrounding Rock [J].Journal of railway engineering society, 2014,31(09): 88-92.

4. MA Shiwei, HAN Xuequan, LIAO Kai. Rail-Time Monitoring and Early Alarms for Collapse Prevention in a Shallow Loess Tunnel with a Large Section[J].Modern tunneling technology,2014,51(02):11-15+22.

5. WU Ke, MA Mingyue, LI Shucai. Monitoring Measurement and Evaluation of Stability in Fujiachong Tunnel[J].Chinese Journal of Underground Space and Engineering,2012,8(03): 543-548.

6. XUE Yiguo, LI Shucai, ZHANG Qingsong, et al. Prediction and early-waning technology of geological hazards in tunnel informational construction[J].Journal of Shandong University (Engineering Science), 2008(05):25-30. 